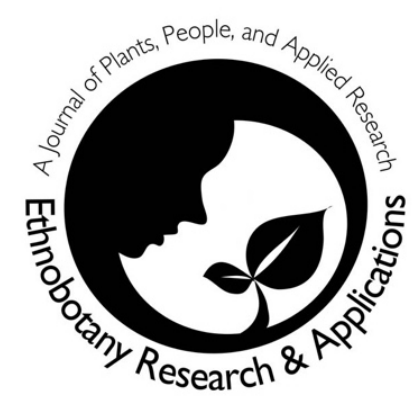

\title{
Phyto-cultural diversity of the Shigar valley (Central Karakorum) Baltistan, Northern Pakistan
}

\author{
Zaheer Abbas, Jan Alam, Said Muhammad, Rainer W. \\ Bussmann, Shujaul Mulk Khan, Manzoor Hussain
}

\section{Research}

\begin{abstract}
Background: An ethnobotanical field study was conducted in 17 villages of the Shigar valley (Central Karakorum Ranges), northern Pakistan to explore the phyto-cultural diversity related to nonethnomedicinal uses.
\end{abstract}

Methods: Eighty-four (84) interviews were conducted in seventeen villages, yielding 52 plant taxa species of 25 families and 46 genera.

Results: The family Asteraceae was dominant followed by Lamiaceae, Rosaceae and Tamaricaceae. The lower temperate zone was used most, with $27(51 \%)$ species while $18(48 \%)$ and 7 $(13 \%)$ species belonged to the sub alpine and alpine zone respectively. Herbs were used most frequently with $27(51 \%)$ species, followed by shrubs $(21,40 \%)$, trees $(4,07 \%)$ and shrub lets $(2,2.85 \%)$. These plants were collected from six types of habitats: viz., moist slopes (17), dry rocky slopes (14), mesic slopes (8), valley waste lands (7) riverbanks (5) and dry sandy plains (1). We also observed particularly interesting usages of the plants in the community of Baltis. The plant uses were grouped in three main categories on the basis of their utilization: viz. food and beverages (4 uses), handicraft and dyeing ( 9 uses), and rituals (6 uses).

Conclusions: The ample utilization of plants demands effective strategies for sustainable management and conservation. Creeping urbanization and population emphasize the preservation and retention of the bio-cultural diversity in the Shigar valley which is crucial for the biodiversity development at national and international levels.

Key words: cultural diversity, conservation, ethnobotany, wild plants, Baltistan

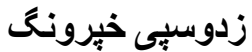

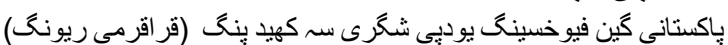

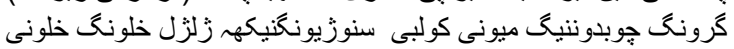

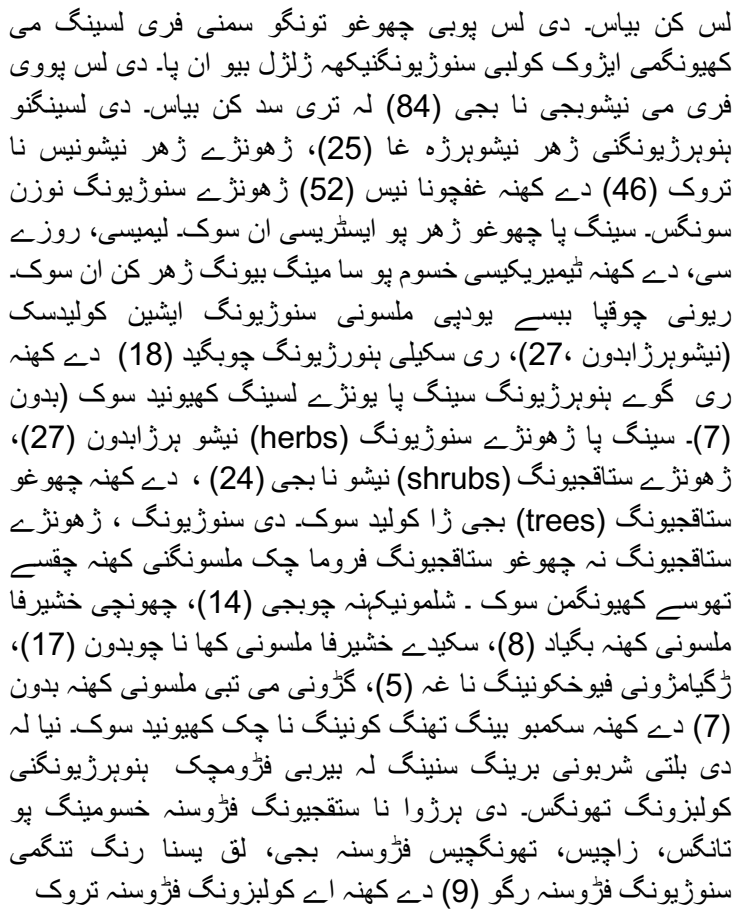

\section{Correspondence}

Zaheer Abbas ${ }^{1 *}$, Jan Alam ${ }^{1}$, Said Muhammad", Rainer W. Bussmann", Shujaul Mulk Khan ${ }^{3}$, Manzoor Hussain ${ }^{1}$

${ }^{1}$ Department of Botany, Hazara University, Mansehra, Pakistan

${ }^{2}$ Ilia State University, Institute of Botany and Bakuriani Alpine Botanical Garden, Department of Ethnobotany, 1 Botanical Str. 0105 Tbilisi, Georgia ${ }^{3}$ Department of Botany, Quaid-i-Azam University, Islamabad, Pakistan

*Corresponding author: zaheerbot@gmail.com

Ethnobotany Research \& Applications

18:31 (2019) 


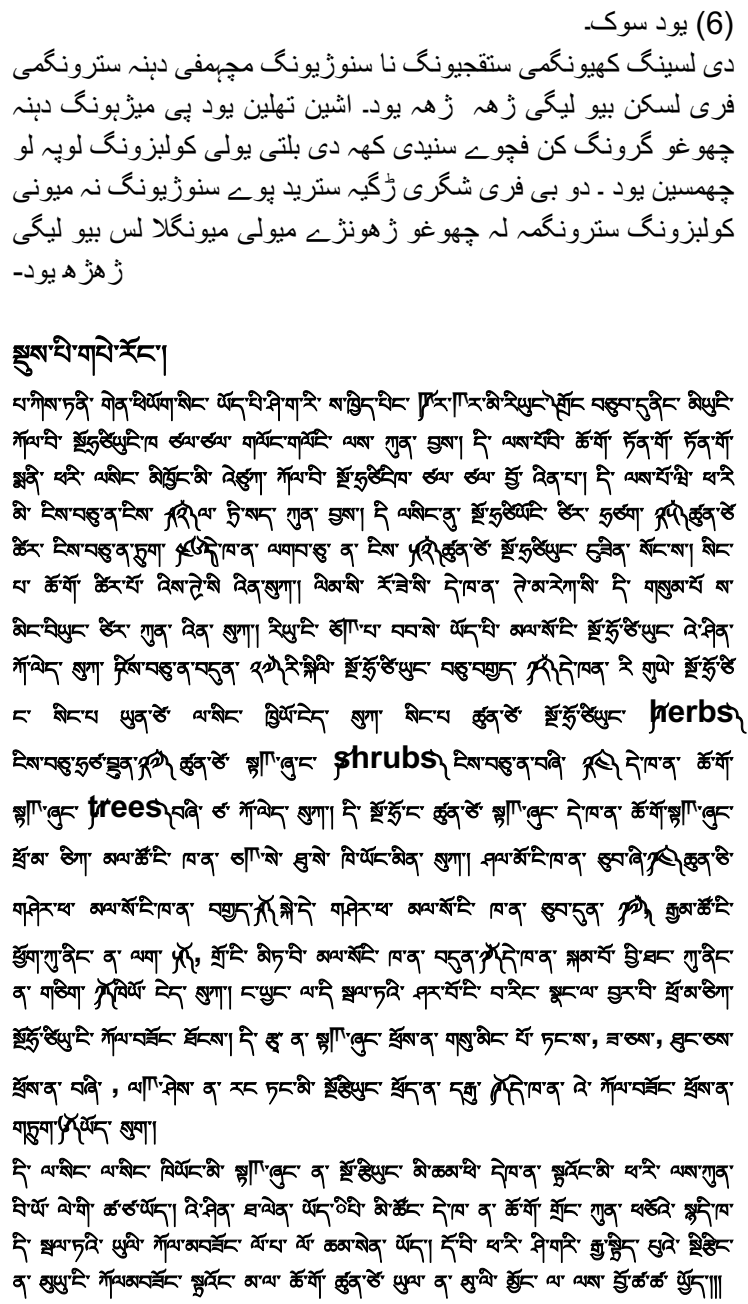

\section{Background}

Baltistan is a typical mountainous territory in the northern Pakistan surrounded by the giant Karakorum and Himalayas ranges. It displays a diverse and unique geology, topography, ethnography, ethnobiology and biological diversity and has often been referred as "Western Tibet" or "Little Tibet" in history. Baltistan covers an area of about $26000 \mathrm{~km}^{2}$ with the average elevation limits of $2100 \mathrm{~m}$ (Afridi 1988). The area is popular for its picturesque valleys for instance Skardu, Rondu, Shigar, Khaplu, Kharmang. However, the remoteness from the country's capital and other large urban areas, difficult accessibility, underdeveloped infrastructure and deficient funding may have always hampered research in the area.

Floristically, Baltistan is included in the IranoTuranian Region (Ali \& Qaiser 1986, Takhtajan 1986). Being a mountainous region Baltistan harbors a taxonomically unique montane flora. Phytogeographically the entire Karakorum is situated at the junction of the Western and Central Asiatic regions of the Tethyan Flora and the altitude greatly effects the relative precipitation and consequently a distinct vegetation zonation formation (Dickoré 1995, Seong et al. 2007). The valley floors show scarce vegetation but with species surrogacy with respect to elevation. The plant species found at Karakorum are taxonomically complex and their distribution is influenced by topography and elevation (Dickoré 1991, Peer et al. 2007).

Previous studies in Shigar include research on local folklore (Hanson 1989, Schuler 1978), geology and glacial history (Seong et al. 2007, 2009), and social settings, socioeconomics and cultural practices (Kreutzmann et al. 2008, Schmidt 2004, 2008). Hartmann (1968) was the first botanist who documented indigenous flora of Biafo glaciers. The ethnomedicinal plants and native flora were explored by Abbas et al. (2017a, 2019). Baltistan is dominated by the Balti people (about 375000 ), of which about 75000 reside in the Shigar valley. The culture of the Balti community is closely linked to the local plants and their products. Our study focused on the nonmedicinal indigenous uses of the local flora.

\section{Methods}

\section{Research Area and Field Work}

The Shigar valley (commonly known as the valley of K2-Peak) is located in the north of the Baltistan region at the right bank of the Indus river. It runs in east-west direction with two sub valleys - Basha and Braldo in the Central Karakorum Ranges covering an area of $4373 \mathrm{~km}^{2}$. It is located at $25^{\circ} 25^{\prime} 32^{\prime \prime} \mathrm{N}$ and $75^{\circ} 42^{\prime} 59^{\prime \prime} \mathrm{E}$ in the elevation range of 2260 to $8611 \mathrm{~m}$ (K2 Godwin Austin). Administratively, it is a newly created district and borders with China (north), Skardu town (south), Nagar valley (west) and Ghanche (east). It exhibits unique physical characteristics with regard to elevation and encompasses highest mountainous ridges, towers and peaks above $6000 \mathrm{~m}$, including mighty K2 (6811m), Broad Peak (8047m), Angel Peak (6858m) and Skil Brum $(7360 \mathrm{~m})$. The valley bottom shows moraines, gorges, and fluvial processes (Abbas et al. 2017b, Schmidt 2004). The sub valleys (Basha, Braldo) extend roughly from $2500-3050 \mathrm{~m}$ in elevation and villages are mostly found on rugged, stony edges of the Shigar, Basha and Braldo rivers (Fig. 1).

More than 30 glaciers over $20 \mathrm{~km}$ in length are found in the Central Karakoram Ranges (Owen 1989, Seong et al. 2007), which represents the largest glacier systems outside the polar regions (Biafo glaciers $63 \mathrm{~km}$, Baltoro $63 \mathrm{~km}$, Chogho Lungma 45km) (Mayer et al., 2006; Quincey et al. 2009). Climates is very hostile and dry (Derbyshire et al. 
2001) and the research area experiences short, dry, hot and sunny summer with intensive radiation providing a very short growing season for native flora. The entire Baltistan region is located in the rain shadow of Himalaya mountains and the monsoon does not reach the territory (Afridi 1988). Early spring and late summer receive scanty rain $(15 \mathrm{~mm}$ per annum) at the valley floor, while at high altitude (above $4500 \mathrm{~m}$ ) precipitation exceeds $200 \mathrm{~mm}$, and permafrost areas exists. Circadian and seasonal temperature fluctuate extremely and rises up to $38^{\circ} \mathrm{C}$ in summer and in winter temperatures fall below $0^{\circ}$, and $-15^{\circ}$ in mid-winter (Owen 1991).

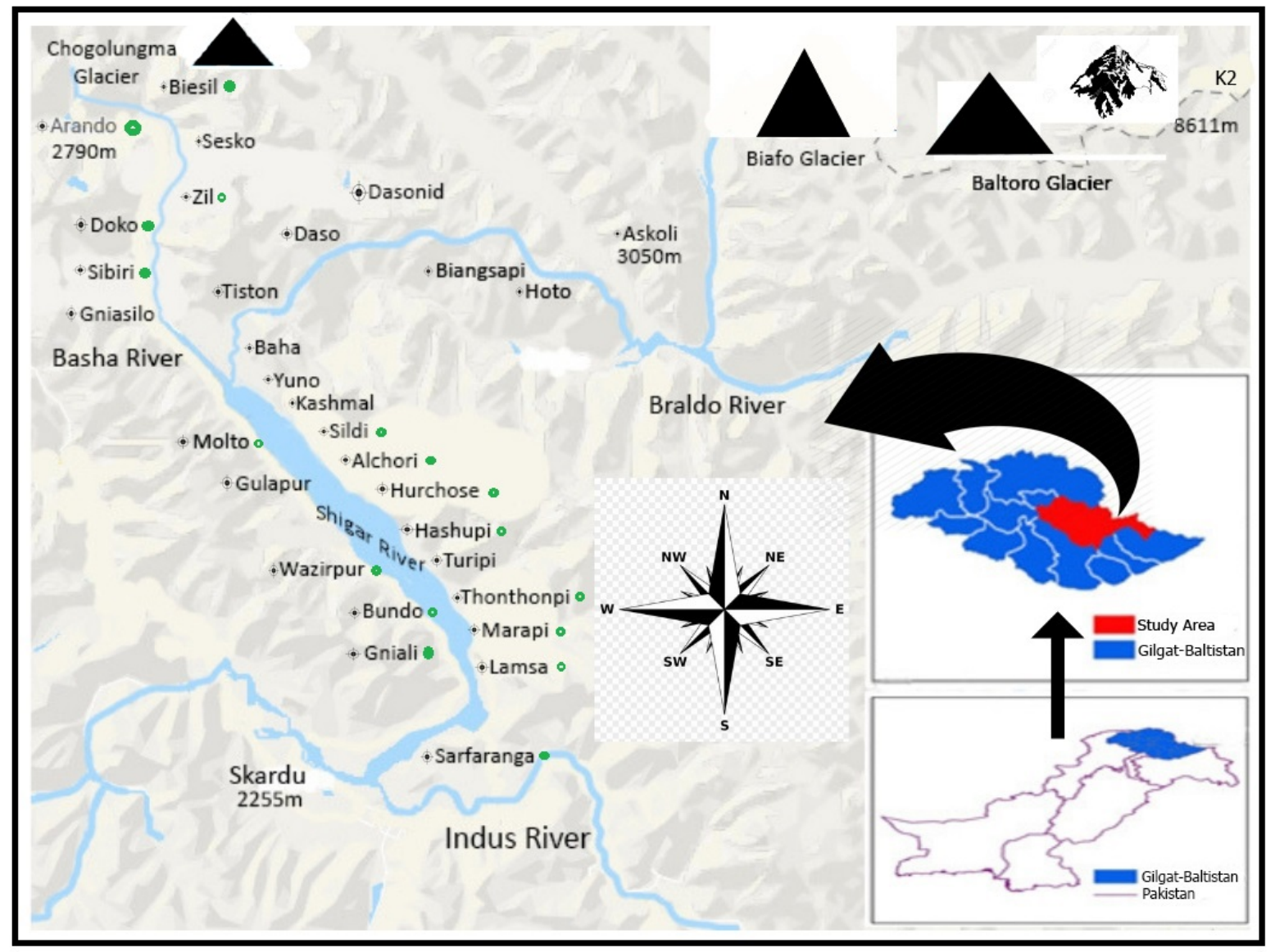

Fig. 1. Map of the study area depicting visited localities.

Until the middle of 19th century the entire Baltistan was governed by local autocratic Raja sovereigns (Maqpoon, Amacha and Yambgo dynasties) (Khan 1987) locally called Chou-Tus (Means: Raja period) and the Shigar was ruled by Raja dynasty known as Amacha. The population of Baltistan migrated from different valleys of the area and from different regions, e.g. Ladakh, Gilgit, Tibet, Hunza, Nagar (Zakir 1991). The Shigar population must probably have migrated from Ladakh, Tibet, Hunza and Nagar. Their cultures intermixed and created a single Balti ethnic group dominated by Ladakhi and Tibetan Balti speakers. The population speaks an archaic non-written Tibetan dialect called Balti (Sprigg 2013). The Balti population has a number of sub-groups (Clan). The population is distributed in villages scattered on alluvial fans, terraces and gentle slopes above the rivers (Shigar, Basha and Braldo), with the main villages located at $2300 \mathrm{~m}$ (Marapi), $2790 \mathrm{~m}$ (Arando) and 3050m (Askole) (Schmidt 2000). Small and seasonal settlement are found in the high alpine zones and comprised of shepherds' houses and cattle homes.

The villages have congested houses and narrow streets in order to save more and more land for agricultural activities. The local people are traditional and tightly immersed in Balti culture, which is reflected in construction, designs of houses and cattle stables, dress, agricultural activities, domestic and farming tools, games and pastoral practices. The recent census of Pakistan conducted in 2017 recorded 75000 people in the project area. Agriculture, animal husbandry, wood cutting, fodder and mining are most common subsistence sources (Abbas et al. 2017a, Kreutzmann et al. 2008). On main valley floor wheat and barley are cultivated with 
different varieties as first crop, followed by corn, millet or buckwheat in July (Kreutzmann 2004). At high altitudes only a single crop reaches maturity, normally buckwheat, potato, pea or beans. The vegetation is dry temperate type (Champion et al. 1965).

\section{Ethnobotanical data collection}

The field study was carried out from 2013-2016 in 17 villages (Fig. 2; Table 1) from valley floor to elevated zones at altitudes of 2300-3000. The hamlets situated at the lowest and highest elevation were Sarfarangah and Askole, respectively. The data about useful plants were collected by using semi structure interviews (Cotton 1996, Martin 2004). Participants were selected randomly but the authors preferred people indicated by villagers to have more indigenous knowledge. Interviews were conducted mostly by the first author in local dialect. Communications were mostly made in houses, gathering place of village, mosques and Jamias, (Islamic schools), forest, alpine pastures, shepherd's homes during plant collections trips. All interviews were only conducted after receiving prior informed consent from each participant. Eighty-four participants of ages ranging from 20 to above 60 were interviewed, including 62 men and 22 women. In local culture women avoid interactions with visitors/tourists and are mostly confined to household and agricultural activities.
Most participants were of an age between 40-60 years (47), followed by $20-40$ years (21) and above 60 years (16). About $75.4 \%$ were illiterate, while $24.6 \%$ was educated mostly to secondary school level or below. The participants engaged in agriculture (56), livestock keeping (7), wood cutting (4), mining (9), were healers (4) and government employees (4) (Table 2).

Respondents were asked about the vernacular names of plants and their etymology, ethnobotanical use(s), part(s) used, availability, distribution and harvesting places. The total ethnobotanical plants were classified according to (Alves and Albuquerque, 2016; Marques, 1995). The specimens were properly pressed, dried and poisoned according to herbarium techniques described by (Jain and Rao, 1977). Plant species were identified by Taxonomists of Hazara University Herbarium, Mansehra Khyber-Pakhtoonkhwa Pakistan, and with the help of available nomenclatural literature (Flora of Pakistan, Ali \& Nasir 1970, Nasir et al. 1972) and flora of china (www.efloras.org/flora_page.aspx?flora_id=2). The botanical names and respective families follow Angiosperm Phylogeny Group (APG 2009) and The Plant List (2010). The plant specimens were given voucher numbers and stored at the Herbarium of Hazara University Mansehra, Pakistan.

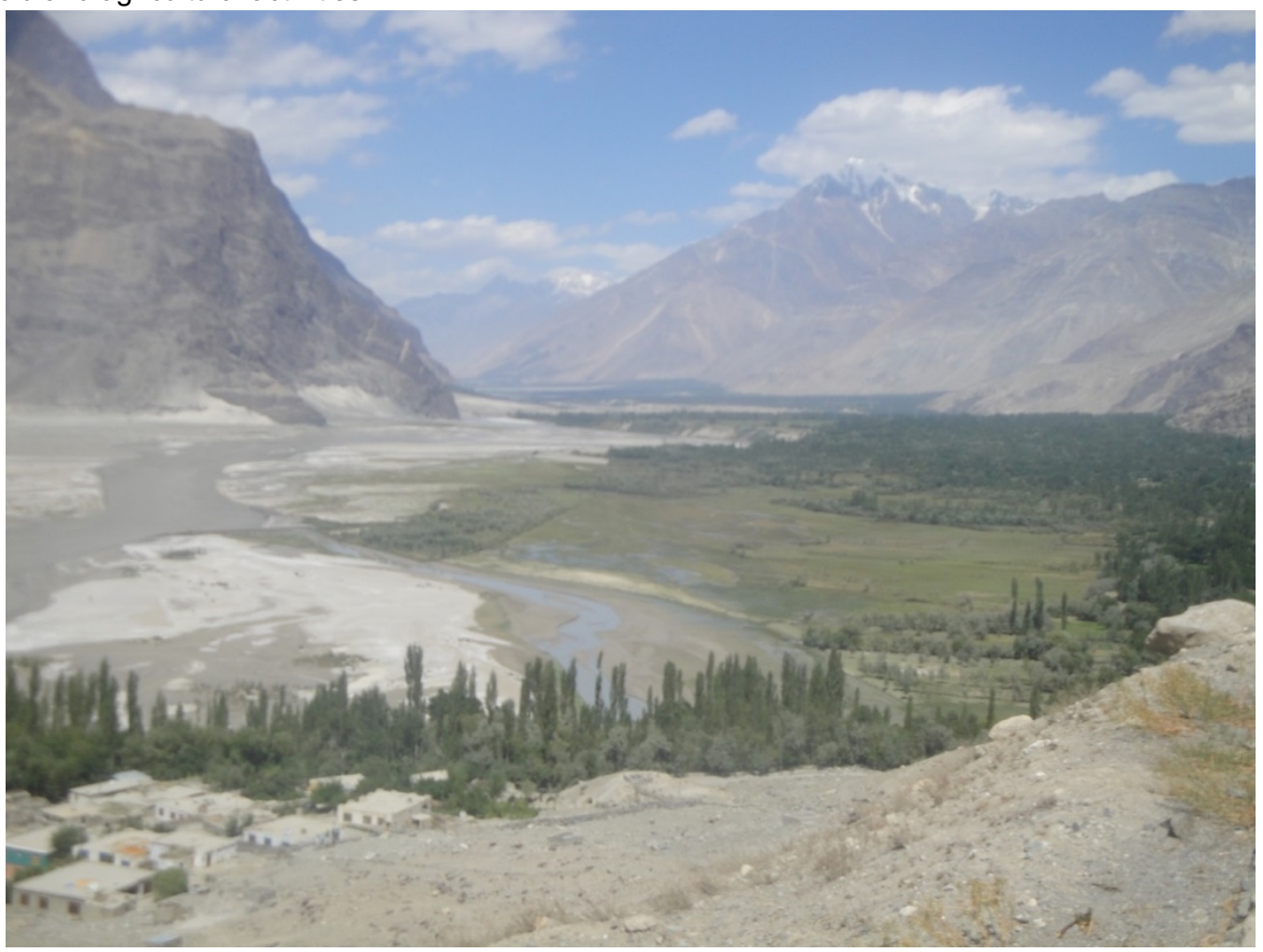

Fig. 2. A topographic view of the study area 
Table 1. Description of visited villages and number of interviews

\begin{tabular}{cccccc}
\hline Villages & Households & Altitude $(\mathbf{m})$ & Latitude & Longitude & Interviews \\
\hline Sarfarangah & 40 & 2217 & N 35 20.595 & E 075 40.208 & 7 \\
Lamsa & 40 & 2256 & N 35 22.933 & E 075 44.967 & 5 \\
Kothang & 22 & 2260 & N 35 25.420 & E 075 44.967 & 8 \\
Thonthonpi & 50 & 2345 & N 35 27.778 & E075 42. 857 & 5 \\
Hashupi & 260 & 2360 & N 35 30.461 & E 075 40.502 & 6 \\
Hurchose & 17 & 2403 & N 25 31.592 & E 075 39.719 & 5 \\
Alchori & 170 & 2381 & N 35 81.424 & E 075 39.049 & 6 \\
Sildi & 80 & 2332 & N 35 34.121 & E 075 35.461 & 3 \\
Zil & 70 & 2623 & N 35 46.601 & E 075 23.650 & 4 \\
Molto & 80 & 2355 & N 35 39.191 & E 075 28.171 & 2 \\
Wazirpur & 70 & 2203 & N 35 390.923 & E 075 35.953 & 5 \\
Bundo & 50 & 2276 & N 35 29.410 & E 075 38.820 & 6 \\
Gniali & 60 & 2276 & N 35 26. 877 & E 075 41.811 & 5 \\
Sibri & 55 & 2580 & N 35 47.399 & E 075 23.845 & 3 \\
Doko & 60 & 2649 & N 35 47.699 & E075 23.683 & 6 \\
Biesil & 65 & 2698 & N 35 52.415 & E 075 23.891 & 4 \\
Arando & 120 & 2799 & N 35 51.953 & E 075 20.079 & 4 \\
\hline 17 & & & & & $\mathbf{8 4}$ \\
\hline
\end{tabular}

Table 2. Demographic features of interviewees

\begin{tabular}{lrr} 
& Number & Percentage \\
\hline Sex Ratio & 49 & $80.33 \%$ \\
Men & 12 & 19.67 \\
Women & 61 & \\
Total & & \\
Age Groups & 18 & 29.5 \\
Between 20 - 40 years & 28 & 45.9 \\
Between 40 - 60 years & 15 & 24.59 \\
Above 60 years & & \\
Education Level & 46 & 75.4 \\
Illiterate & 3 & 4.92 \\
Primary & 4 & 6.55 \\
Middle & 3 & 4.92 \\
High School & 2 & 3.28 \\
Graduate & 3 & 4.92 \\
Masters & & \\
Social Livelihoods & 38 & 62.29 \\
Farmers & 5 & 8.19 \\
Shepherds & 4 & 6.55 \\
Wood cutters & 8 & 13.11 \\
Gemstone workers & 3 & 4.92 \\
Healers & 3 & 4.92 \\
Job Holders & & \\
Life type & 26 & 42.62 \\
Town area & 35 & 57.37 \\
Elevated areas & & \\
\hline &
\end{tabular}

\section{Result and Discussion}

\section{Diversity of ethnobotanical plants}

Our interviews yielded 52 species in 25 families and 46 genera. Asteraceae was recorded as the prevalent family with 5 species. Lamiaceae, Rosaceae and Tamaricaceae followed with four species each. These families were commonly used in other mountain areas like Tuchal, Zagroz, Hindukush, Himalaya and Karakorum Mountains (Akhani et al. 2013, Chawla et al. 2008, Khan 2007, Noroozi et al. 2008). Asteraceae is considered highly advanced and specialized in morphology, occupying many ecological niches (Barreda et al. 2012, Xiaoping \& Bremer 1993). The species of Rosaceae and Lamiaceae are also found in many mountain systems (Nasir et al. 1972) (Table 3).

\section{Local nomenclature}

The vernacular nomenclature gives accounts about the local names in Balti dialect of plant species used for cultural, food and medicinal purposes. In some cases, pronunciation and spelling differed for the same species. For instance, the local name of Thymus linearis was recorded as "Tumburuk" while few respondents used "Tumburu". The local name of Datura stramonium was "Datura" but in few cases noted as "Isman Datura". 
Table 3. Phyto-cultural diversity of the Shigar valley Central Karakorum Ranges, Northern Pakistan

\begin{tabular}{|c|c|c|c|c|c|c|c|}
\hline $\begin{array}{l}\text { Family / Botanical } \\
\text { name family }\end{array}$ & Local name & Zone/Habit & $\begin{array}{l}\text { Harvesting } \\
\text { area }\end{array}$ & $\begin{array}{l}\text { Part(s) } \\
\text { used }\end{array}$ & $\begin{array}{l}\text { Traditional } \\
\text { uses }\end{array}$ & $\begin{array}{l}\text { No. } \\
\text { of } \\
\text { uses }\end{array}$ & Use description \\
\hline $\begin{array}{l}\text { Alliaceae / Allium } \\
\text { carolinianum DC. }\end{array}$ & Broq chong & Alpine/herb & $\begin{array}{l}\text { Moist } \\
\text { slopes }\end{array}$ & Bulbs & Condiment & 1 & $\begin{array}{l}\text { Bulbs are cut and fried with oil and used in } \\
\text { culinary. Being an alpine species, it is used } \\
\text { mostly by shepherds and wood cutters in the } \\
\text { elevated areas }\end{array}$ \\
\hline $\begin{array}{l}\text { Amaranthaceae / } \\
\text { Chenopodium album L. }\end{array}$ & Snio & Temperate/herb & $\begin{array}{l}\text { Valley } \\
\text { waste } \\
\text { lands \& in } \\
\text { cultivated } \\
\text { fields }\end{array}$ & $\begin{array}{l}\text { Whole } \\
\text { plant }\end{array}$ & Wild vegetable & 1 & $\begin{array}{l}\text { The collected fresh plants are cooked and } \\
\text { used as vegetable. }\end{array}$ \\
\hline $\begin{array}{l}\text { Amarantnaceae / } \\
\text { Chenopodium foliosum } \\
\text { (Moench) Asch. }\end{array}$ & $\begin{array}{l}\text { Spang } \\
\text { Osae }\end{array}$ & Temperate/herb & $\begin{array}{l}\text { Mesic } \\
\text { slopes }\end{array}$ & Fruits & Wild fruit & 1 & $\begin{array}{l}\text { The fruits are picked and eaten in the sub } \\
\text { alpine areas. }\end{array}$ \\
\hline $\begin{array}{l}\text { Apiaceae / Carum carvi } \\
\text { L. }\end{array}$ & Thalae & Subalpine/herb & $\begin{array}{l}\text { Moist } \\
\text { slopes }\end{array}$ & Seeds & Condiment & 1 & $\begin{array}{l}\text { used in local sweat and salty cookies called } \\
\text { Kulcha. }\end{array}$ \\
\hline $\begin{array}{l}\text { Apiaceae / Pimpinella } \\
\text { diversifolia DC. }\end{array}$ & Kohniod & Subalpine/herb & $\begin{array}{l}\text { Moist } \\
\text { slopes }\end{array}$ & Seeds & Drinks & 1 & $\begin{array}{l}\text { Seeds are boiled to make local drink called } \\
\text { gehva. }\end{array}$ \\
\hline $\begin{array}{l}\text { Apiaceae } \\
\text { Pleurospermum } \\
\text { candollei (DC.) C.B. } \\
\text { Clark }\end{array}$ & $\begin{array}{l}\text { Braq / } \\
\text { Shundun }\end{array}$ & Alpine/herb & $\begin{array}{l}\text { Moist } \\
\text { slopes }\end{array}$ & $\begin{array}{l}\text { Whole } \\
\text { plant }\end{array}$ & Wild vegetable & 1 & $\begin{array}{l}\text { Branches are collected, boiled in water and } \\
\text { fried in oil to make a local vegetable called } \\
\text { sonma. }\end{array}$ \\
\hline $\begin{array}{l}\text { Asteraceae / Artemisia } \\
\text { absinthium L. }\end{array}$ & Khampa & Temperate/herb & $\begin{array}{l}\text { Valley } \\
\text { waste } \\
\text { lands }\end{array}$ & Branches & Bio repellent & 1 & $\begin{array}{l}\text { Branches are cut and keep in the } \\
\text { house or shake to get rid of common domestic } \\
\text { flies. }\end{array}$ \\
\hline $\begin{array}{l}\text { Asteraceae / Artemisia } \\
\text { brevifolia Wall ex DC. }\end{array}$ & Bustae & Temperate/shrub & $\begin{array}{l}\text { Dry rocky } \\
\text { slopes }\end{array}$ & $\begin{array}{l}\text { Whole } \\
\text { plant }\end{array}$ & Fuel wood & 1 & $\begin{array}{l}\text { Very common plant and profusely distributed in } \\
\text { the area. Whole plants are uprooted and burnt } \\
\text { for heating purpose in winter or cooking } \\
\text { purpose. }\end{array}$ \\
\hline $\begin{array}{l}\text { Asteraceae / Cichorium } \\
\text { intybus L. }\end{array}$ & Shantha & Temperate/herb & $\begin{array}{l}\text { Valley } \\
\text { waste } \\
\text { lands }\end{array}$ & $\begin{array}{l}\text { Whole } \\
\text { plant }\end{array}$ & Wild vegetable & 1 & $\begin{array}{l}\text { Gathered materials cooked and fried and used } \\
\text { as vegetable. }\end{array}$ \\
\hline $\begin{array}{l}\text { Asteraceae / Erigeron } \\
\text { flaccidus (Bunge) } \\
\text { Botsch. }\end{array}$ & Ghzima & Alpine/herb & $\begin{array}{l}\text { Moist } \\
\text { slopes }\end{array}$ & Flowers & Affection & 1 & $\begin{array}{l}\text { The flowers are collected by shepherds, wood } \\
\text { cutters and by alpine visitors given to lower } \\
\text { villagers as affection. }\end{array}$ \\
\hline
\end{tabular}


Ethnobotany Research and Applications

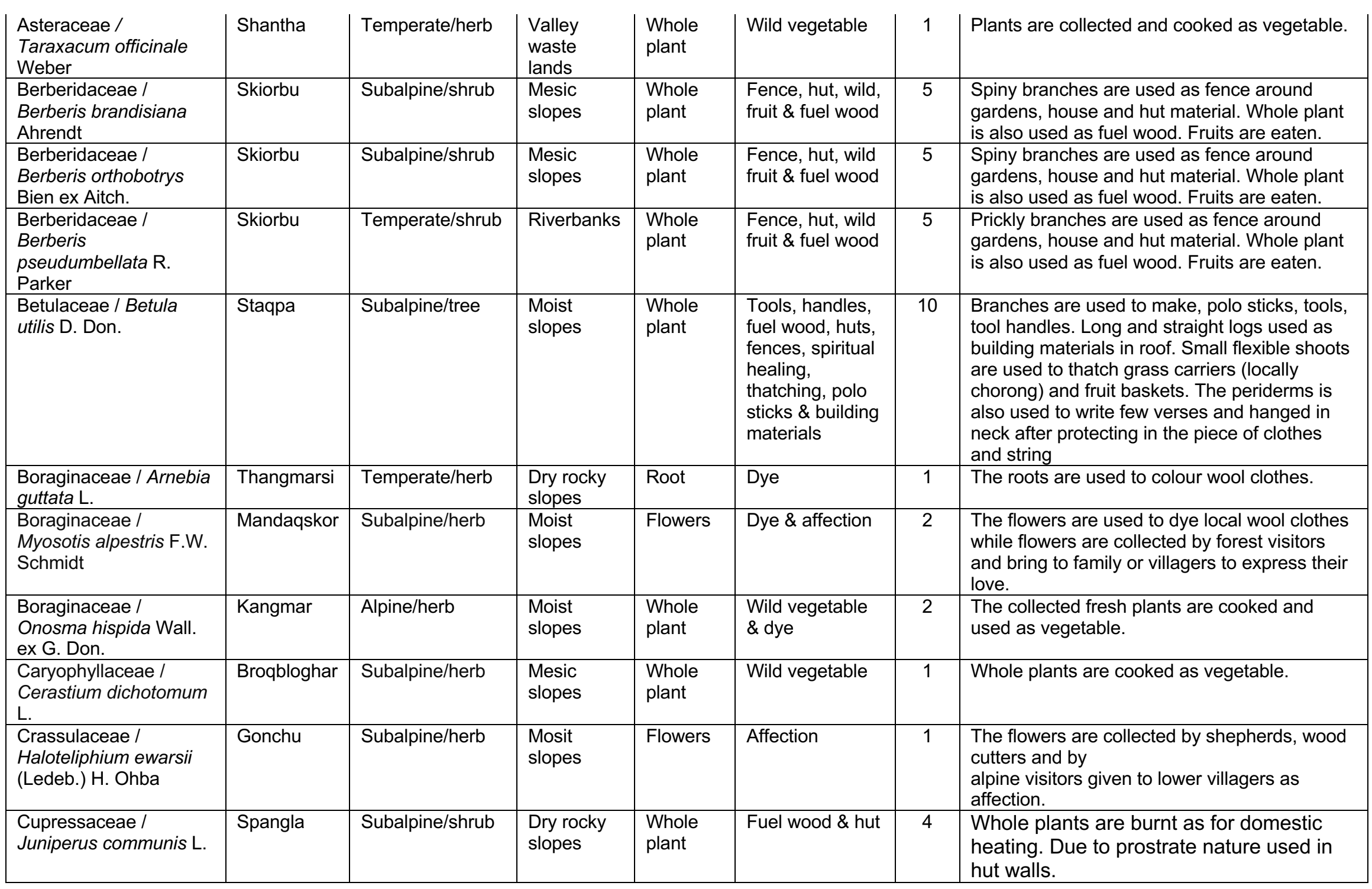

Published: 23 October 2019

http://dx.doi.org/10.32859/era.18.31.1-18 


\begin{tabular}{|c|c|c|c|c|c|c|c|}
\hline $\begin{array}{l}\text { Cupressaceae / } \\
\text { Juniperus excelsa M } \\
\text { Bieb. }\end{array}$ & Shukpa & Subalpine/tree & $\begin{array}{l}\text { Dry rocky } \\
\text { slopes }\end{array}$ & $\begin{array}{l}\text { Stem \& } \\
\text { branches }\end{array}$ & $\begin{array}{l}\text { Fuel wood, hut, } \\
\text { rituals \& building } \\
\text { materials }\end{array}$ & 5 & $\begin{array}{l}\text { It is one of the principal fuel wood wild trees in } \\
\text { the area next to birch. Shoots are used for hut } \\
\text { making and logs used in roofing. }\end{array}$ \\
\hline $\begin{array}{l}\text { Elaeagnaceae / } \\
\text { Hippophe rhamnoides } \\
\text { subsp. turkestanica } \\
\text { Rousiss }\end{array}$ & Karxoq & Temperate/shrub & $\begin{array}{l}\text { Moist } \\
\text { slopes }\end{array}$ & $\begin{array}{l}\text { Friuts \& } \\
\text { branches }\end{array}$ & $\begin{array}{l}\text { Wild fruits, } \\
\text { fence, hut \& fuel } \\
\text { wood }\end{array}$ & 4 & $\begin{array}{l}\text { The taxon is widely distributed shrub used for } \\
\text { different purpose. Due to its prickly nature } \\
\text { ideal for fencing and hut. The wood is perfect } \\
\text { for winter heating and coal. Fruits are eaten } \\
\text { fresh and considered medicine. Local jams } \\
\text { and scarp are made. }\end{array}$ \\
\hline $\begin{array}{l}\text { Fabaceae / Astragalus } \\
\text { polemius Boissier. }\end{array}$ & $\begin{array}{l}\text { Biowa } \\
\text { chrachu }\end{array}$ & Temperate/herb & $\begin{array}{l}\text { Dry rocky } \\
\text { slopes }\end{array}$ & $\begin{array}{l}\text { Whole } \\
\text { plant }\end{array}$ & Bio epellent & 1 & $\begin{array}{l}\text { The whole plant are uprooted and kept in the } \\
\text { hole of kitchen and store rooms in order to } \\
\text { avoid worms and rates to keep healthy foods } \\
\text { and grains. }\end{array}$ \\
\hline $\begin{array}{l}\text { Fabaceae / Cicer } \\
\text { microphyllum Benth. }\end{array}$ & $\begin{array}{l}\text { Broq } \\
\text { pokhstran }\end{array}$ & Temperate/herb & $\begin{array}{l}\text { Moist } \\
\text { slopes }\end{array}$ & $\begin{array}{l}\text { Whole } \\
\text { plant }\end{array}$ & Wild vegetable & 1 & $\begin{array}{l}\text { The whole plant is used to make local } \\
\text { vegetables }\end{array}$ \\
\hline $\begin{array}{l}\text { Fabaceae / Colutea } \\
\text { paulsonii ssp. paulsonii } \\
\text { (Shap. ex Ali) Ali }\end{array}$ & Rbana & Temperate/shrub & $\begin{array}{l}\text { Dry rocky } \\
\text { plains }\end{array}$ & $\begin{array}{l}\text { Whole } \\
\text { plant }\end{array}$ & $\begin{array}{l}\text { Thatching \& } \\
\text { brooms }\end{array}$ & 2 & $\begin{array}{l}\text { The flexible branches are used to thatch local } \\
\text { grass carriers and makebaskets, thatched } \\
\text { walls. ong and straight branches are used as } \\
\text { brooms. }\end{array}$ \\
\hline $\begin{array}{l}\text { Fragaria nubicola } \\
\text { (Hook.f.) Lindl.ex } \\
\text { Lacaita / Rosaceae }\end{array}$ & $\begin{array}{l}\text { Spang } \\
\text { Osae }\end{array}$ & Subalpine/herb & $\begin{array}{l}\text { Mesic } \\
\text { slopes }\end{array}$ & Fruits & Wild fruit & 1 & The fresh fruit are eaten. \\
\hline $\begin{array}{l}\text { Grossulariaceae / Ribes } \\
\text { alpestre Decne. }\end{array}$ & Askuta & Temperate/shrub & $\begin{array}{l}\text { Dry rocky } \\
\text { slopes }\end{array}$ & $\begin{array}{l}\text { Stem, } \\
\text { branches } \\
\& \text { fruits }\end{array}$ & $\begin{array}{l}\text { Fence, hut, fuel } \\
\text { wood, \& wild } \\
\text { fruit }\end{array}$ & 4 & $\begin{array}{l}\text { Fruits are eaten as wild fruits. Branches and } \\
\text { stem are used for different purposes like } \\
\text { fencing, hut and fuel wood. }\end{array}$ \\
\hline $\begin{array}{l}\text { Grossulariaceae / Ribes } \\
\text { himalense Royle ex } \\
\text { Decne. }\end{array}$ & Askuta & Subalpine/shrub & $\begin{array}{l}\text { Dry rocky } \\
\text { slopes }\end{array}$ & $\begin{array}{l}\text { Stem, } \\
\text { branches } \\
\& \text { fruits }\end{array}$ & $\begin{array}{l}\text { Fence, hut, fuel } \\
\text { wood, \& wild } \\
\text { fruit }\end{array}$ & 4 & $\begin{array}{l}\text { Fruits are eaten as wild fruits. Branches and } \\
\text { stem are used for different purposes like } \\
\text { fencing, hut and fuel wood. }\end{array}$ \\
\hline $\begin{array}{l}\text { Grossulariaceae / Ribes } \\
\text { orientale Desf. }\end{array}$ & Askuta & Subalpine/shrub & $\begin{array}{l}\text { Dry rocky } \\
\text { slopes }\end{array}$ & $\begin{array}{l}\text { Stem, } \\
\text { branches } \\
\text { \& fruits }\end{array}$ & $\begin{array}{l}\text { Fence and hut, } \\
\text { fuel wood \& wild } \\
\text { fruit }\end{array}$ & 4 & $\begin{array}{l}\text { Fruits are eaten as wild fruits. Branches and } \\
\text { stem are used for different purposes like } \\
\text { fencing, hut and fuel wood. }\end{array}$ \\
\hline $\begin{array}{l}\text { Lamiaceae / } \\
\text { Dracocephalum nutans } \\
\text { L. }\end{array}$ & Shundun & Alpine/herb & $\begin{array}{l}\text { Mesic } \\
\text { slopes }\end{array}$ & $\begin{array}{l}\text { Whole } \\
\text { plant }\end{array}$ & Wild vegetable & 1 & $\begin{array}{l}\text { The fresh branches are collected and } \\
\text { used as vegetable. }\end{array}$ \\
\hline $\begin{array}{l}\text { Lamiaceae / Isodon } \\
\text { rugosus (Wall.ex } \\
\text { Benth.) Codd }\end{array}$ & Fiangma & Temperate/herb & $\begin{array}{l}\text { Dry rocky } \\
\text { slopes }\end{array}$ & $\begin{array}{l}\text { Whole } \\
\text { plant }\end{array}$ & Broom & 1 & $\begin{array}{l}\text { Whole plant is uprooted and used as } \\
\text { broom in houses. }\end{array}$ \\
\hline $\begin{array}{l}\text { Lamiaceae / Mentha } \\
\text { royleana Benth }\end{array}$ & Foling & Temperate/herb & $\begin{array}{l}\text { Moist } \\
\text { places }\end{array}$ & Leaves & Condiment & 1 & $\begin{array}{l}\text { The leaves were collected and used in salads, } \\
\text { curd and curries. }\end{array}$ \\
\hline
\end{tabular}


Ethnobotany Research and Applications

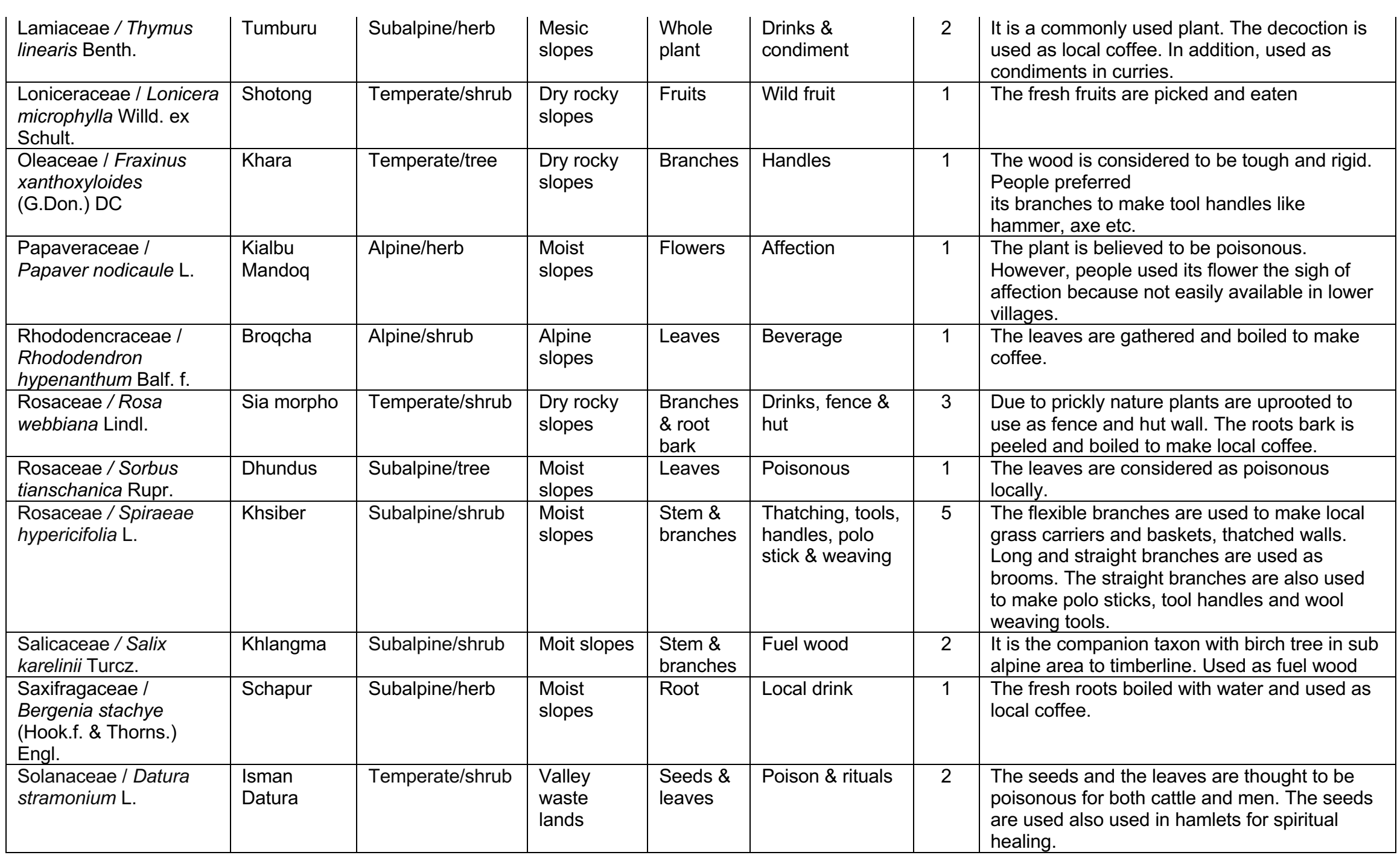

Published: 23 October 2019

http://dx.doi.org/10.32859/era.18.31.1-18 
Ethnobotany Research and Applications

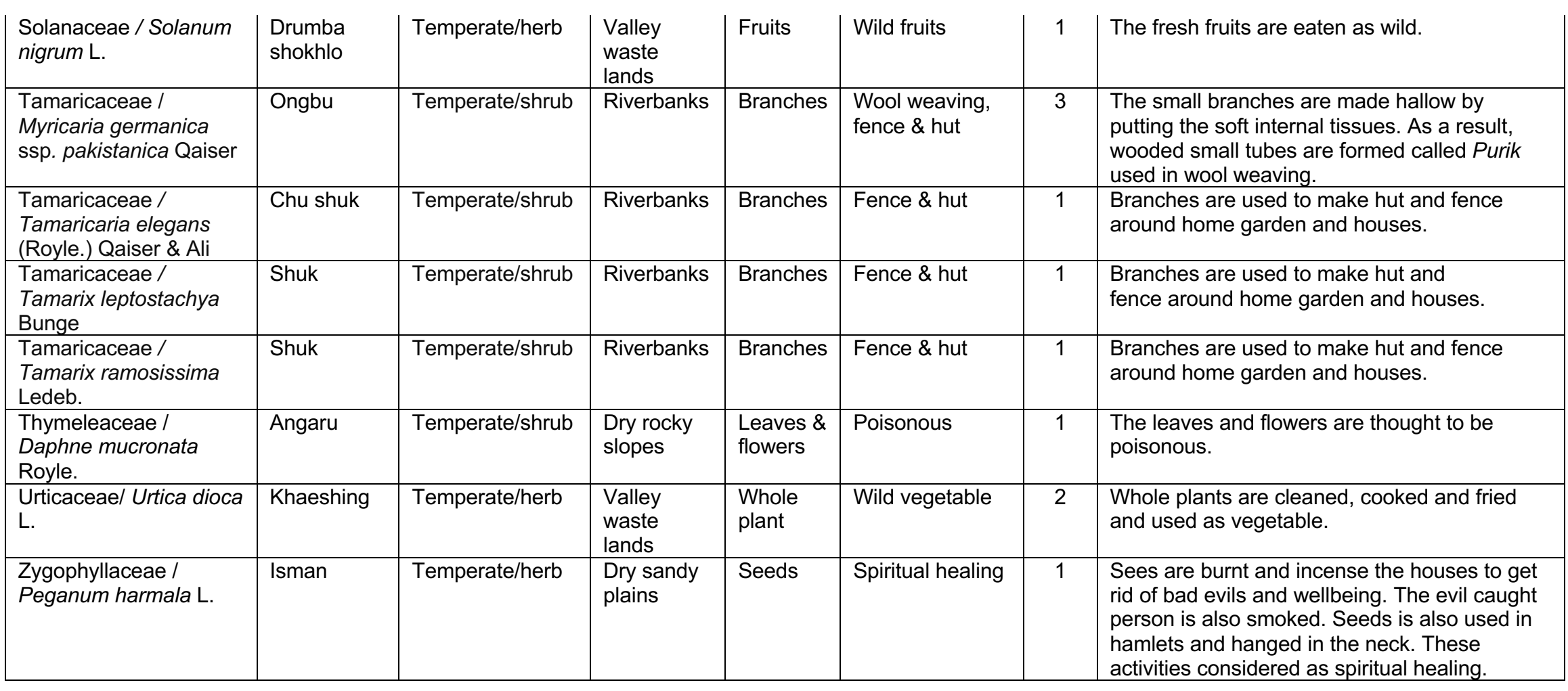


Artemisia absinthium was called Kho bustae and Shadi bustae in the local community. Kho bustae is the name of Artemisia santolinifolia derived from its bitter taste (Kho:bitter, bustae any species of Artemisia). It was also called Shadi bustae (monkey like plants) referring to its dense indumentum.

In some cases, local names referred to growth habit, myths, social associations, habitat type, stem structure, fruit characters and medicinal uses. For instance, the vernacular name of Arnebia guttata is "Thangmarsti or thangmarsi" (pronounced thangmar-sti from thang:dry or desert area, mar derived from morpho:red, sti:ink). The name is given due to its distribution in dry and arid areas, and its use for producing red dye from the roots. Broq chong (broq:forest, chong:onion) is the local name of Allium carolinianum because of its occurrence in the forest, but not in the lower valley bottom. The fruits of Solanum nigrum resemble grapes (Vitis sp.) and the local name is drumba shokhlo (from drumba:homegarden and shokhlo:type of grape). The local name of Pleurospermum candollei is braq shunadun (from braq:rocky, type of shundun which grows in rocky areas) because it grows in rocky habitats. Likewise, kangmar (from kangma:foot and marfo:red) is the name of Onosma hispida i.e. plant with red "foot" as its roots are red in color. Astragalus psilocentros is used to trap rats and locally called Biowa-charchu (from biowa:rat). This species prevents rats from nesting in stores, homes, cattle barns etc. Spang-osae (from spang:grassy habitat and osae:mulberry) is the name of Chenopodium foliosum which has mulberry like fruits and grows on grassy slopes.

\section{Plant collection and habit}

Herbaceous species were most frequently used (27 species, $51 \%)$ followed by shrubs $(21,40 \%)$, trees $(4,7 \%)$ and sub-shrubs $(2,2.85 \%)$. In the mountain habitats the harsh environmental condition supports the growth of herbaceous species (Chang 1981, Körner 2000). As a result, herbs succeeded in any type of floristic studies in the montane system (Mahdavi et al. 2013). Plants were collected from six types of habitats:dry rocky slopes (14), mesic slopes (8), moist slopes (17), river bank (5) and valley waste lands (7).

\section{Plant-people interaction}

There is an inextricable link between the biological diversity and human culture (Barbier et al., 2011, Cocks 2006). The altitudinal distribution of plant species showed a maximum use of species from lower temperate zones 27 (51\%) species, while 18 $(48 \%)$ and $7(13 \%)$ species were found to occur in the sub alpine and alpine zone respectively. The diversity of ethnobotanical plants showed a clear inverse relation with altitude also described by Saqib et al. (2011) in the Himalayan range.

Every ethnic group has culture and possesses tales about its ethnology, linguistics and social system. Plant uses were grouped into three categories 1) food and beverages (beverages, condiments, wild food, wild vegetables), 2) handicrafts and dyeing (dye, brooms, fence, handles, hut, polo sticks, thatch, tools, weaving), 3) rituals (affection, biorepellent, fuel, building materials, poisons and spiritual healing). The number of plants used for certain purpose was recorded as plants for affection (4 species), bio-repellent (2 species), broom (2 species), building materials (8 species), condiments (9 species), fence (12 species), fuel (14 species), dye (3 species), handles (5 species), hut (14 species), local dish (6 species), local drinks (4 species), poisonous (3 species), polo stick (4 species), thatching (4 species), tools (5 species), weaving (5 species), ritual (6 species) mystical healing, wild fruit ( 11 species) and wild vegetable (7 species). The largest number of species was using as fuel wood, for the construction of huts, as wild fruits, fencing and wild vegetables. These varied traditional uses represent an interesting bio-cultural diversity but can trigger a decline in biodiversity due to unsustainable utilization. In many mountain communities, people's first priority is to cover their day to day needs, and knowledge about the intrinsic value of biological diversity is limited. Consequently, many plant species are always under anthropogenic pressure. A number of studies advised the need for more sustainable utilization of local resources due to profusely increasing global population along with climate change (Pimentel and Pimentel, 2006).

\section{Detailed plant uses \\ Food and beverages}

Wild edible plants are consumed in different ways ( Fentahun and Hager 2009, Pieroni 2000) and many populations in the world use wild plants as vegetable, fruits, condiments, and beverages, providing minerals, vitamins and trace elements (Pieroni et al. 2017, Rasingam 2012). In the study area indigenous food selection was classified into four sub-categories i.e. beverages ( 5 species), condiments (9), wild fruits (10) and wild vegetables (9). In the study area Pimpinella diversifolia, Thymus linearis, Rosa webbiana, Bergenia stachye and Carum carvi were used to make local tea. Some of these beverages were used as medicine.

The local perception is that herbal teas serve for relaxation of muscles after laborious work. Kurppa et al. (1983) found that herbal teas can be very effective for female reproductive disorders, and such decoctions are rich in natural antioxidants (Pieroni et 
al. 2017). Allium carolinianum, Carum carvi, Mentha royleana, and Thymus linearis were used as spices and flavoring in curries and local dishes (Prdapu, Kisir, Khanda, Muskut, chol, Tro bhalae) on daily basis. The seeds of Carum carvi were used in local cookies (Azoq, Kulcha, Khurba and Zdairchung). Berberis brandisiana, $B$. orthrobotorys, $B$. pseudoumbellata, Chenopodium foliosum, Fragaria nubicola, Hippophe rhamnoides, Lonicera microphylla, Ribes alpestre, R.himalynse, $R$. orientale, Rhamnus prostrata and Solanum nigrum. In Zimbabwe wild fruits are the only fruit source and considerable income is generated by its trading (Campbe 1987). Urtica dioca, Pleurospermum candollei, Taraxacum officinale, Onosma hispida and Dracocephalum nutans were frequently used as wild vegetable species. These were cooked separately or mixed with other species and might be adding micronutrients to the diet (Ogle et al. 2001) and alleviate the dietary deficiency (Flyman \& Afolayan 2006).

\section{Handicrafts and dyeing}

Plants produce natural dyes and the practice of dying is common among indigenous people (MacFoy 2004). Woolen clothes are one of the cultural expressions of the study area. The wool of local sheep and ewe is used to design caps, clothes and waist coats. In order to color the white wool Myosotis alpestre (whole), Onosma hispida (root), and Arnebia guttata are used as dyees. Nowadays these clothes are however used only by old people of the local area. The knowledge of plants for dye use are also common in other communities e.g. in Turkey (Doğan et al. 2003) and in the valleys of India (Kala 2009).

Small branches of Colutea paulsenii, Kochia prostrata, and Isodon rugosus were used to make brooms, like in other areas of Pakistan (Panhwar \& Abro 2007). The construction of huts mostly used in summer is a common tradition in mountain regions. Balti people migrate to these huts to care for their livestock. The twigs, branches and stem of certain plant species are used to build huts, and the walls are often made from woven branches instead of other materials (Fig. 3). This construction is called Shaq. Fences are built around home gardens, vegetable fields and other crop fields to protect these for herbivorous animals. The most commonly used species for the construction of Shaq were Betula utilis, Juniperus excelsa, Juniperus communis, Ribes alpestre, $R$. himalense, $R$. orientale, Myricaria germanica, Tamaricria elegans. Plants with straight branches with hard and tough wood are selected in order to make agricultural tools and their handles and ploughs. Betula utilis and Fraxinus xanthoxylioides were the most used species.

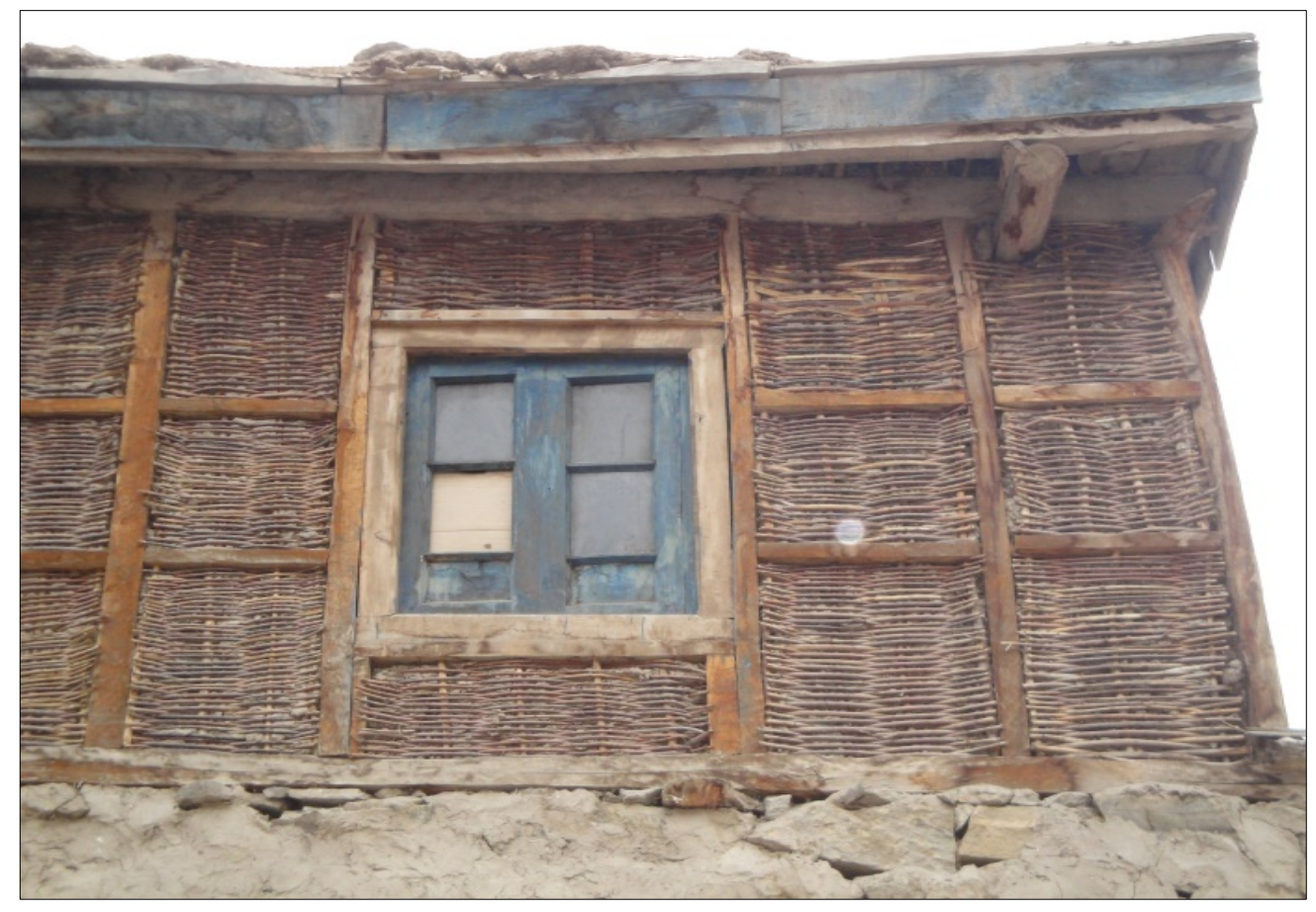

Fig. 3. A typical house with woven walls (shaq nang) 
Polo is the common game in entire region of Baltistan and is played at special occasions and cultural days. The species which are selected for polo sticks and balls were Spiraea hypericifolia and Betula utilis. The small twigs and branches of Betula utilis, Spirarea hypericifolia and Colutea paulsenii were used to make baskets (Tondol), manure carriers (Chorong) and grass carrier (Chura) (Fig. 4). Tondol is used to collect fruits like apricot, grape and mulberry and for safe storage. Baskets are made of different sizes and shapes and used to collect fruits directly from trees in order to prevent squeezing/pressing and for transportation. Chorong is commonly used to transport cattle manures to agricultural fields. Chura is longer and bigger and is used to bring grass, braches and hay/straw from agricultural fields. Similar baskets are used in other regions of Pakistan (Ahmad et al. 2010). Livestock is one of the income sources of indigenous people particularly in high altitude villages, and Balti people keep especially goats and sheep. The wool is used for clothes, local blanket, carpets and caps. In order to weave these, looms (Threesa) with various accessories are made by local carpenters using the wood of Myricaria germanica. The weaver is known as Thaqskan locally. In Baltistan these cultural expressions are in danger however, especially due to increasing accessibility to modern markets, where varieties of local and imported clothes and blankets are available. These skillful weavers are unfortunately usually not supported and encouraged by villagers. It was also indicated by the villagers that the livestock wool now is sold in local markets and used for quilt. The preservation of these cultural practices may be possible if vocational centers at village level are developed.

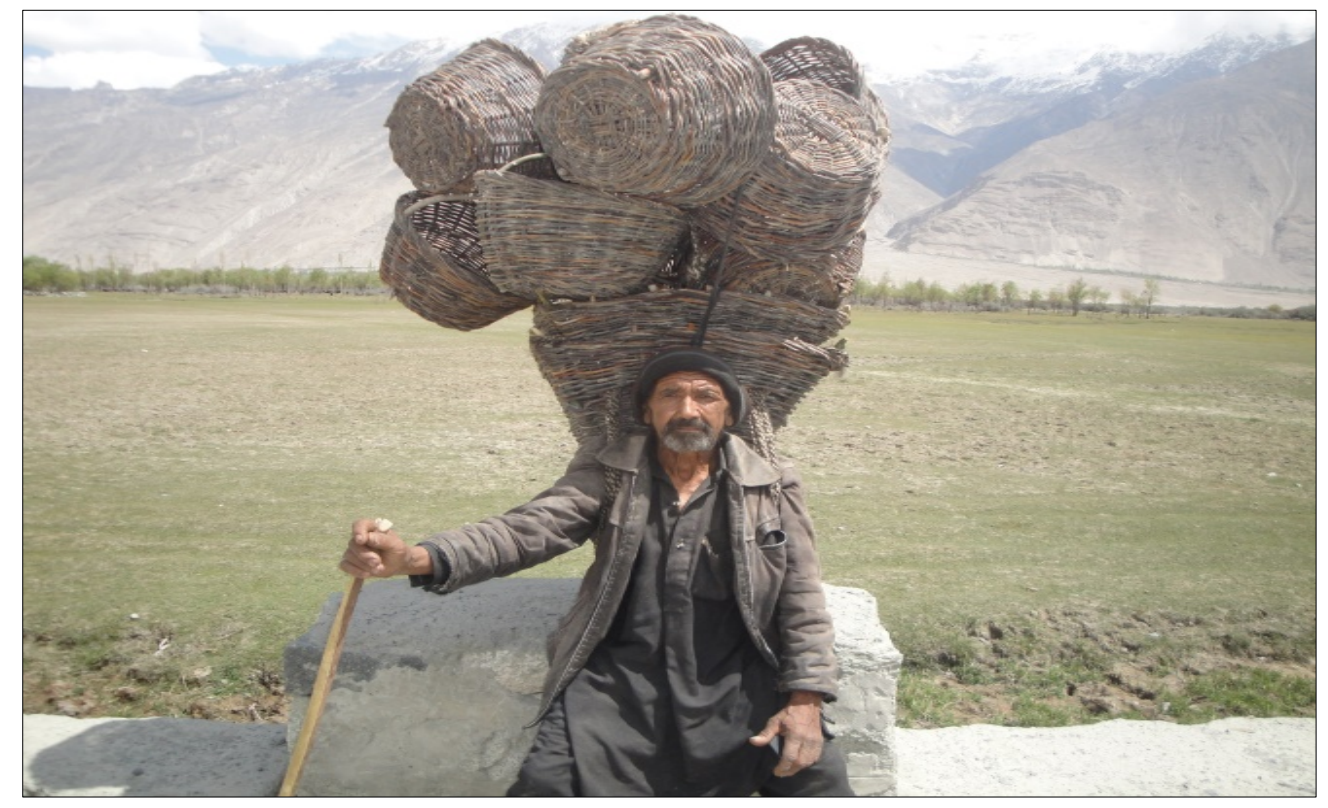

Fig. 4. A man carrying woven baskets for sale

\section{Ritual uses}

Flowers are believed to be the sign of love and are given to someone to express love and affection in many cultures. In the study area especially Haloteliphium ewarsii, Papaver nuadicaule, Myosotis alpestre, Primula warshenewskiana and Erigeron flaccidus are collected to be given to beloved family members. Astagalus psilocentrose, Artemisia absinthium, Ribes orietale, Berberis pseudoumbellata were used to repel rats, snakes, insects, centipedes, millipedes and other insects. These species act due to their prickles, bitter taste and pungent scent (Abbas et al. 2016, Isman 2000). The house design in mountain regions tends to reflect the challenging climate (Ooka 2002). In the lower parts of the study valley house are mainly built using cultivated timber species Populus alba, Populus nugra, Plantanus orientalis, Prunus Armeniaca, Salix alba etc. In the upper valley, Betula utilis, Juniperus communis, Juniperus excelsa, Salix karnelii and Fraxinus xanthoxyloides were used for construction. Hippophae rhamnoides, Artemsia brevifolia, and Kochia prostrate were often used as firewood at lower altitudes, while Betula, Juniperus, Berberis, Ribes and Rosa were used at higher altitudes. Like in other areas, the consumption of wood for domestic fuel and construction purpose greatly influences the population of shrubs and tree species, and may lead to erosion (Ogunkunle \& Oladele, 2004). This urges the implement an 
effective conservation and management plans (Heltberg et al. 2000, Rawat et al. 2009).

Datura stramonium, Daphne mucronata and Sorbus tianschanica are believed to be poisonous, as they are not eaten by any animal.

Ailments of unknown origin are believed to be caused by the devil or by spirits, and plant species like Betula utilis, Juniperus excelsa, Peganum harmala, and Datura stramonium were used to treat such ailments. These beliefs and practices are centuries old and it is very difficult to trace their history. The practices transfer from generation to generation and only older participants practiced the custom. The spiritual healing potential by plants was also reported by other authors (Aldridge 1991, Giday et al. 2016).

\section{Multiuse plants}

The valley inhabitants were using plants for wide range of purposes. Thirty-one plant were used for single use, seven species had two uses, three had three, 5 species had 5 uses, and only one species (Betula utilis) had more than 5 uses and was under severe anthropogenic pressure. The highly utilized species were Betula utilis (10 uses), Berberis species (5), Juniperus excelsa (5), Ribes species (5), Spiraeae hypericifolia (5), Hippophae rhamnoides ssp. turkestanica (4) and Juniperus communis (4) (Fig. 5).

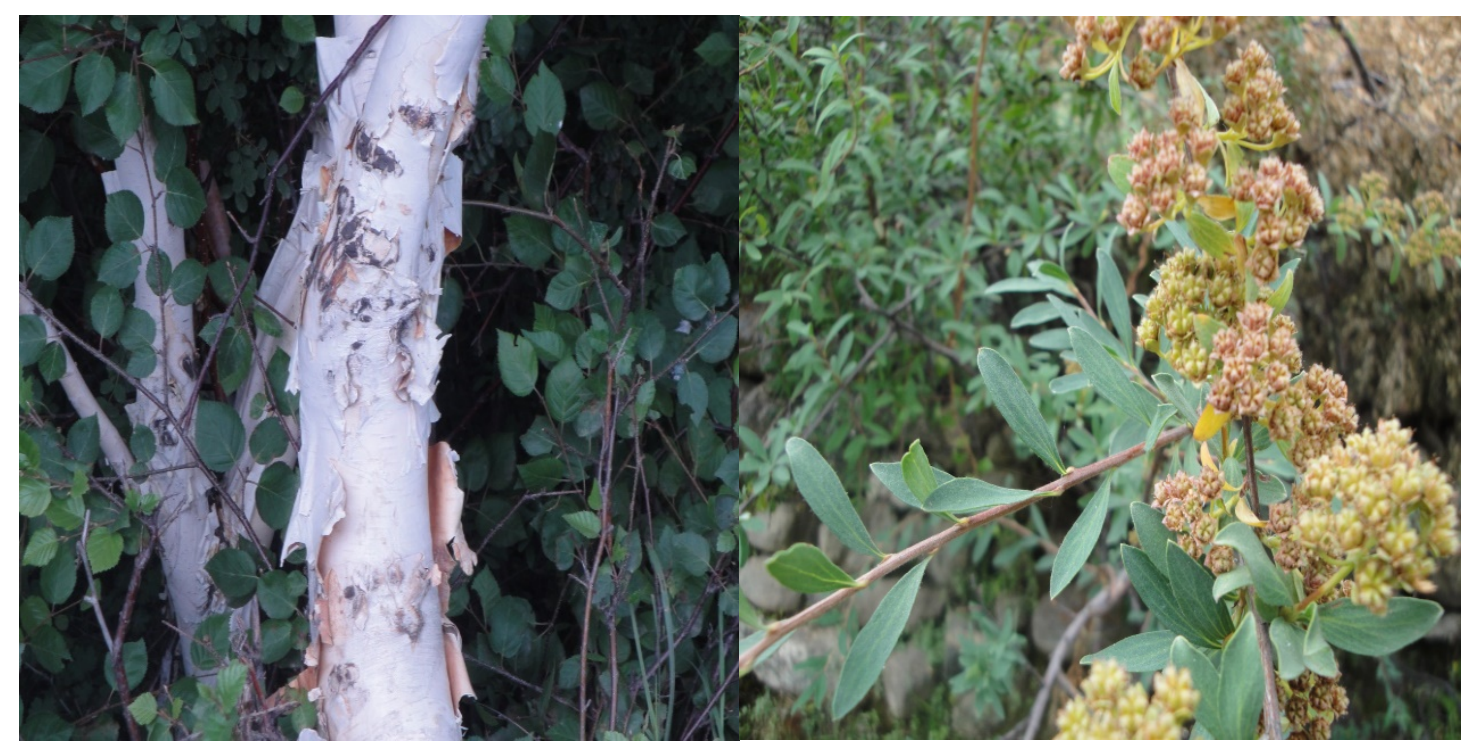

Fig. 5. Two multi-purpose of the study area - Betula utilis (left) and Spiraea hypericifolia (right)

\section{Novelty of the study}

The study is the first of its nature from the region and explored the extensive relations of the indigenous flora and the Balti community. Species used for beverages, e.g. Pimpinella diversifolia, Thymus linearis, Rosa webbiana, Bergenia stachye and Carum carvi have been reported for the first time. The first two species are also used as condiments in the Himalayan belt of Pakistan (Abbasi et al. 2012). Similarly, among wild fruits the species, Berberis sp., Ribes sp. and Rhamnus prostrata were recorded for the first time. Myosotis alpestre, Onosma hispida and Arnebia guttata were originally reported for medicinal purposes, but here were reported as dye for the first time. Betula utilis, Juniperus excelsa, Juniperus communis, Ribes alpestre, $R$. himalense, $R$. orientale, Myricaria germanica, Tamaricria elegans are common species for fencing, hedge and hut making and are common in the whole region of Baltistan, including the study area. Betula utilis and
Fraxinus xanthoxylioides were reported for medicinal importance for the first time in this study, and only from the study region. Similarly, the use of Spiraea hypericifolia, Colutea paulsenii and Betula utilis for thatch were reported for the first time from the study area. Haloteliphium ewarsii, Papaver nuadicaule, Myosotis alpestre, Primula warshenewskiana and Erigeron flaccidus were recorded by Abbas et al. (2016) from the same community. Similarly, the plants of spiritual healing i.e. Betula utilis, Juniperus excelsa, Peganum harmala and Datura stramonium were also reported for the first time from the region.

\section{Conclusions}

The population of Shigar valley presented an interesting phyto-cultural diversity that needs to be conserved. The younger generations have unfortunately little interest in such activities, because they are engaged in modern businesses and endeavors. Their thought and priorities focus on 
modern markets for their necessities, and since cultural practices are time taking and laborious activities these are no longer valued. Consequently, the number of experts of handicrafts, e.g. weaving, thatching and dyeing is decreasing with the passage of time. Local vocational centers for indigenous handicraft would be an effective effort for the retention of phyto-culture and profitable for locals to generate income without complex and expensive machineries. The processes of urbanization and modernization are increasing in the area leading to a loss of indigenous knowledge with the passage of time. Establishing handicraft shops and centers in the valley may be helpful for the retention and restoration of these interesting cultural practices. Nurseries of ethnobotanically important plants may be an effective tool to foster sustainable utilization. Therefore, the current study encourages governmental, non-governmental organizations and national institutes to protect the biodiversity, cultural diversity and ethnobiology. A dedicated and effective management plan for the preservation of ethnobotanical knowledge and practices is needed.

\section{Declarations}

\section{Abbreviations: N/A.}

Ethics approval and consent to participate: Consent was obtained from all participants before conducting interviews. No further ethics approval was required.

\section{Consent for publication: N/A}

\section{Availability of data and materials: N/A}

Competing interests: The authors declare that they have no competing interests.

Funding: No funding was provided by any source to conduct this survey.

Authors' contributions: ZA designed the survey, conducted field work, data collection and wrote the manuscript, JA identified the collection, SMK and $\mathrm{MH}$ were the supervisors of the PhD work of ZA, SM helped in herbarium techniques and data computation, RWB revised and improved the manuscript. All authors read, corrected, and approved the manuscript.

\section{Acknowledgements}

All authors are very grateful to the people of the valley for their hospitality, co-operation and sharing their knowledge. We are also thankful to Mr. Nisar Ali
Khasman for his help in writing abstracts of Balti, both in Persian and Yige scripts.

\section{Literature cited}

Abbas, Z. 2012. Floristic diversity, cultural uses and phytosociology of Tormic valley Baltistan. M. Phil Thesis, Quaid-i-Azam University, Islamabad, Pakistan.

Abbas Z, Khan SM, Abbasi AM, Pieroni A, Ullah Z, Iqbal M, Ahmad Z. 2016. Ethnobotany of the Balti community, Tormik valley, Karakorum range, Baltistan, Pakistan. Journal of Ethnobiology and Ethnomedicine 12:38.

Abbas Z, Khan SM, Alam J, Khan SW, Abbasi AM. 2017a. Medicinal plants used by inhabitants of the Shigar Valley, Baltistan region of Karakorum rangePakistan. Journal of Ethnobiology and Ethnomedicine 13:53.

Abbas Z, Khan SM, Alam J, Ullah Z, Khan SW, and Alam N. 2017b. Species, diversity and phyto-climatic gradient of a montane ecosystem in the Karakorum Range. Pakistan Journal of Botany 49(SI):89-98.

Abbasi AM, Khan MA, Ahmad M, Zafar M. 2012. Medicinal Plant Biodiversity of Lesser HimalayasPakistan. Springer, London, UK.

Afridi, BG. 1988. Baltistan in history. Emjay Books International, Islamabad, Pakistan.

Ahmad F, Khan, MA, Ahmad M, Zafar M, Mahmood T, Jabeen A, Marwat SK. 2010. Ethnomedicinal uses of grasses in the Salt Range Region of Northern Pakistan. Journal of medicinal plants research 4, 362-369.

Akhani H, Mahdavi P, Noroozi J, Zarrinpour V. 2013. Vegetation patterns of the Irano-Turanian steppe along a 3,000 $\mathrm{m}$ altitudinal gradient in the Alborz Mountains of Northern Iran. Folia Geobotanica 48:229-255.

Aldridge D. 1991. Spirituality, Healing and Medicine. Jessica Kingsley Publishers, London, UK.

Ali SI, and Qaiser M. 1986. A phytogeographical analysis of the phanerogams of Pakistan and Kashmir. Proceedings of the Royal Society of Edinburgh. Section B. Biological Sciences 89:89101.

Alves, AGC, Albuquerque UP. 2016. Ethnobiology or Ethnoecology? In Introduction to Ethnobiology Edited by AGC Alves \& UP Albuquerque. Springer, London, UK. Pp. 15-18.

Barbier EB, Hacker SD, Kennedy C, Koch EW, Stier AC, Silliman BR. 2011. The value of estuarine and coastal ecosystem services. Ecological monographs 81:169-193. 
Barreda VD, Palazzesi L, Katinas L, Crisci JV, Tellería MC, Bremer K, Passala MG, Bechis F, Corsolini R. 2012. An extinct Eocene taxon of the daisy family (Asteraceae): evolutionary, ecological and biogeographical implications. Annals of Botany 109:127-134.

Campbe B. 1987. The use of wild fruits in Zimbabwe. Economic botany 41:375-385.

Champion S.H., Seth SK, Khattak G.1965. Forest types of Pakistan. Pakistan Forest Institute, Peshawar, Pakistan.

Chang D. 1981. The vegetation zonation of the Tibetan Plateau. Mountain Research and Development 1:29-48.

Chawla A, Rajkumar S, Singh K, Lal B, Singh R, Thukral A. 2008. Plant species diversity along an altitudinal gradient of Bhabha Valley in western Himalaya. Journal of Mountain Science 5:157-177.

Cocks M. 2006. Biocultural diversity:moving beyond the realm of 'indigenous' and 'local'people. Human Ecology 34:185-200.

Cotton CM. 1996. Ethnobotany:principles and applications. John Wiley \& Sons. Ltd., Chichester, UK.

Derbyshire E, Fort M, Owen LA. 2001. Geomorphological Hazards along the Karakoram Highway:Khunjerab Pass to the Gilgit River, Northernmost Pakistan (Geomorphologische Hazards entlang des Karakorum Highway:Khunjerab $\mathrm{Paß}$ bis zum Gilgit River, nördlichstes Pakistan). Erdkunde 55:49-71.

Dickoré WB. 1991. Zonation of flora and vegetation of the Northern declivity of the Karakoram/Kunlun Mountains (SW Xinjiang China). GeoJournal 25:265284.

Dickoré WB. 1995. Systematische Revision und chorologische Analyse der Monocotyledoneae des Karakorum (Zentralasien, West-Tibet). Flora Karakorumensis:1. Angiospermae, Monocotyledoneae. Flora of the Karakorum, including a record of species from adjacent mountains of High Asia (east Pamir, west Kunlun, northeast Hindukush, northwest Himalaya, west Tibet):1. Angiospermae, Monocotyledoneae. Stapfia, Germay.

Doğan Y, Başlar S, Mert HH, Ay G. 2003. Plants used as natural dye sources in Turkey. Economic Botany 57:442-453.

Fentahun MT, Hager H. 2009. Exploiting locally available resources for food and nutritional security enhancement:wild fruits diversity, potential and state of exploitation in the Amhara region of Ethiopia. Food Security 1:207.
Flyman, M., and A. Afolayan. 2006. The suitability of wild vegetables for alleviating human dietary deficiencies. South African Journal of Botany 72:492-497.

Giday K, Lenaerts L, Gebrehiwot K, Yirga G, Verbist B, Muys B. 2016. Ethnobotanical study of medicinal plants from degraded dry afromontane forest in northern Ethiopia:Species, uses and conservation challenges. Journal of Herbal Medicine 6:96-104.

Group AP. 2009. An update of the Angiosperm Phylogeny Group classification for the orders and families of flowering plants:APG III. Botanical Journal of the Linnean Society 161:105-121.

Hanson CR. 1989. The northern suture in the Shigar valley, Baltistan, northern Pakistan. In Tectonics of the western Himalayas Edited by LL Malinconico \& Lillie RJ. Geological Society of America, USA. Pp. 203-216.

Hartmann H. 1968. Über die Vegetation des Karakorum. Vegetatio 15:297-387.

Heltberg R, Arndt TC, Sekhar NU. 2000. Fuelwood consumption and forest degradation:a household model for domestic energy substitution in rural India. Land Economics:213-232.

Isman MB. 2000. Plant essential oils for pest and disease management. Crop protection 19:603-608.

Jain S, Rao R. 1977. A handbook of field and herbarium technique. Today and Tomorrow Publishers, New Delhi, India.

Kala CP. 2009. Aboriginal uses and management of ethnobotanical species in deciduous forests of Chhattisgarh state in India. Journal of Ethnobiology and Ethnomedicine 5:20.

Khan H. 1987. History of Baltistan. Lok Virsa Translation. Islamabad, Pakistan.

Khan SW. 2007. Inventoring and monitoring the flora of Haramosh and Bugrote valleys Gilgit, Gilgit Batistan. PhD Thesis. University of Karachi, Karachi, Pakistan.

Körner C. 2000. The alpine life zone under global change. Gayana Botanica 57:1-8.

Kreutzmann H. 2004. Pastoral practices and their transformation in the North-Western Karakoram. Nomadic Peoples 8:54-88.

Kreutzmann H., Schmidt, M., Benz, A., 2008. The Shigar Microcosm:Socio-economic Investigations in a Karakoram Oasis Northern Areas of Pakistan. Technical Report, Berlin, Germany.

Kurppa K, Holmberg PC, Kuosma E, Saxen L.1983. Coffee consumption during pregnancy and selected congenital malformations:a nationwide case-control study. American journal of public health 73:13971399. 
MacFoy C. 2004. Ethnobotany and sustainable utilization of natural dye plants in Sierra Leone. Economic Botany 58:66-76.

Mahdavi P, Akhani H, Maarel EV. 2013. Species diversity and life-form patterns in steppe vegetation along a $3000 \mathrm{~m}$ altitudinal gradient in the Alborz Mountains, Iran. Folia Geobotanica 48:7-22.

Marques JGW. $1995 . \quad$ Pescando pescadores:etnoecologia abrangente no baixo São Francisco alagoano. University of Sao Paulo Press, Brazil.

Martin G. 2004. Ethnobotany. A methods manual. People and plants conservation series. WWF. Earthscan Publications, UK.

Mayer C, Lambrecht A, Belo M, Smiraglia C, Diolaiuti G. 2006. Glaciological characteristics of the ablation zone of Baltoro glacier, Karakoram, Pakistan. Annals of Glaciology 43:123-131.

Nasir E, Ali S, Stewart RR. 1972. Flora of West Pakistan:an annotated catalogue of the vascular plants of West Pakistan and Kashmir. Fakhri Press, Karachi, Pakistan.

Noroozi J, Akhani H, Breckle SW. 2008. Biodiversity and phytogeography of the alpine flora of Iran. Biodiversity and Conservation. 17:493-521.

Ogle BM, Hung PH, Tuyet HT. 2001. Significance of wild vegetables in micronutrient intakes of women in Vietnam:an analysis of food variety. Asia Pacific Journal of Clinical Nutrition 10:21-30.

Ogunkunle A, Oladele F. 2004. Ethnobotanical study of fuelwood and timber wood consumption and replenishment in Ogbomoso, Oyo State, Nigeria. Environmental Monitoring and Assessment 91:223236.

Ooka R. 2002. Field study on sustainable indoor climate design of a Japanese traditional folk house in cold climate area. Building and Environment 37:319-329.

Owen L. Derbyshire E. 1989. The Karakoram glacial depositional system. Zeitschrift für Geomorphologie 36:33-73.

Owen LA. 1991. Mass movement deposits in the Karakoram Mountains:their sedimentary characteristics, recognition and role in Karakoram landform evolution. Zeitschrift für Geomorphologie 35:401-424.

Panhwar AQ, Abro H. 2007. Ethnobotanical studies of Mahal Kohistan (Khirthar national park). Pakistan journal of Botany 39:2301-2315.

Peer T, Gruber JP, Millinger A, Hussain F. 2007. Phytosociology, structure and diversity of the steppe vegetation in the mountains of Northern Pakistan. Phytocoenologia 37:1-65.
Pieroni A. 2000. Medicinal plants and food medicines in the folk traditions of the upper Lucca Province, Italy. Journal of Ethnopharmacology 70:235-273.

Pieroni A, Soukand R, Quave CL, Hajdari A, Mustafa B. 2017. Traditional food uses of wild plants among the Gorani of South Kosovo. Appetite 108:83-92.

Pimentel D, Pimentel M. 2006. Global environmental resources versus world population growth. Ecological economics 59:195-198.

Quincey D, Copland L, Mayer C, Bishop M, Luckman A, Belò M. 2009. Ice velocity and climate variations for Baltoro Glacier, Pakistan. Journal of Glaciology 55:1061-1071.

Rasingam L. 2012. Ethnobotanical studies on the wild edible plants of Irula tribes of Pillur Valley, Coimbatore district, Tamil Nadu, India. Asian Pacific Journal of Tropical Biomedicine 2:1493-1497.

Rawat YS, Vishvakarma SC, Todaria N. 2009. Fuel wood consumption pattern of tribal communities in cold desert of the Lahaul valley, North-Western Himalaya, India. Biomass and Bioenergy 33:15471557.

Saqib Z, Malik RN, Shinwari MI, Shinwari ZK. 2011. Species richness, ethnobotanical species richness and human settlements along a Himalayan altitudinal gradient:Prioritizing Plant Conservation in Palas Valley, Pakistan. Pakistan journal of Botany 43:129133.

Schmidt M. 2000. Pastoral systems in Shigar/Baltistan:communal herding management and pasturage rights. In High Mountain Pastoralism in Northern Pakistan Edited by $\mathrm{E}$ Ehlers \& $\mathrm{H}$ Kreutzmann. Franz Steiner Verlag, Stuttgart, Germany. Pp.121-150.

Schmidt M. 2004. Interdependencies and Reciprocity of Private and Common Property Resources in the Central Karakorum (Interdependenzen und Reziprozität von Privat-und Allmende-Ressourcen im Zentralen Karakorum). Erdkunde. 58:316-330.

Schmidt M. 2008. Land use, land administration and land rights in Shigar, Baltistan. In Modern Ladakh. Anthropological perspectives on continuity and change Edited by MV Beek \& F Pieri. Brill Publishers, Boston USA. Pp. 241-266.

Schuler S. 1978. Story of the creation of the Shigar (facsimile, transliteration, and translation). Central Asiatic Journal. 22:102.

Seong YB, Bishop MP, Bush A, Clendon P, Copland L, Finkel RC, Kamp U, Owen LA, and Shroder JF. 2009. Landforms and landscape evolution in the Skardu, Shigar and Braldu valleys, central Karakoram. Geomorphology 103:251-267. 
Seong YB, Owen LA, Bishop MP, Bush A, Clendon P, Copland L, Finkel U, Kamp R, Shroder JF. 2007. Quaternary glacial history of the Central Karakoram. Quaternary Science Reviews. 26:3384-3405.

Sprigg RK, 2013. Balti-English/English-Balti Dictionary. RoutledgeCurzon. Taylor \& Francis Group, New York, USA.

Takhtajan A. 1986. Floristic regions of the world. (Translated by TJ Crovello.) University of California Press, USA.

Waller P, Bernes G, Thamsborg S, Sukura A, Richter S, Ingebrigtsen K, Höglund J. 2001. Plants as deworming agents of livestock in the Nordic countries:historical perspective, popular beliefs and prospects for the future. Acta Veterinaria Scandinavica 42:3.

Xiaoping Z, Bremer K. 1993. A cladistic analysis of the tribe Astereae (Asteraceae) with notes on their evolution and subtribal classification. Plant Systematics and Evolution 184, 259-283.

Zakir CM. 1991. Siachen Glacier:the World's Highest Battlefield. Urdu (Baltistan, Pakistan:Baltistan Academy, Ali Abad, Skardu. 